Impact of marketing costs and the research and development

Dr. Bassant Badr Eldin Abdo \& Dr. Walid Aboubakr

\title{
Impact of marketing costs and the research and development on the profitability of Egypt's pharmaceutical companies
}

\author{
Bassant Badr Eldin Abdo \\ PhD in Accounting (Cairo University, Egypt) \\ Walid Aboubakr
}

PhD in Management( (International Academy of Engineering and media Sciences, Egypt)

\section{Abstract}

The main objective of this study is to examine the impact of marketing and R\&D expenditures on the competitiveness of Egypt's pharmaceutical companies. In this report, Egypt Stock Exchange admitted pharmaceutical companies. Data estimator random-effect panel was used for this purpose. The results indicate that variables such as the size of a business, the capitalto-total ratio of assets and the debt-to-asset ratio affect profitability. Nonetheless, on competitiveness, business life, advertisement costs and spending in $R \& D$ are unsuccessful. Legal concerns such as the absence of patent law and the framework for pricing are reasons for the poor partnership between R\&D and marketing costs and its effect on income, The results indicate that variables such as the size of a business, the capital--ratio of assets and the debt--ratio affect profitability. Nonetheless, on competitiveness, business life, advertisement 
Impact of marketing costs and the research and development

Dr. Bassant Badr Eldin Abdo \& Dr. Walid Aboubakr

costs and spending in $\mathrm{R} \& \mathrm{D}$ are unsuccessful. Regulatory problems including the lack of $\&$ absence of patent law and pricing controls are reasons for the poor partnership between $\mathrm{R} \& \mathrm{D}$ and marketing costs and its impact on the Egyptian pharmaceutical industry's profitability.

Keywords: marketing costs, Research and development, profitability, pharmaceutical companies

\section{Introduction}

In economic decisions, income is regarded as essential knowledge (Grabowski and Mueller, 1978). Investors, executives and financial analysts have also used profit as a benchmark for dividend benefit payment, as a measuring instrument for management efficiency, for forecasting decision-making, and as an assessment method (Schall and Haley, 1980). Accordingly, several researchers have attempted to classify the factors that influence the competitiveness of companies (Griliches, 1979). Research and development (R\&D) and marketing related costs are two factors influencing the competitiveness of businesses. Therefore, several researchers have tried to recognize the $R \& D$ plays a key role in the pharmaceutical industry, and the production of new medicines is extremely vital for the patentbased competitiveness of companies. On the other hand, the drug and health services represent a significant amount of worldwide 
Impact of marketing costs and the research and development

Dr. Bassant Badr Eldin Abdo \& Dr. Walid Aboubakr

ads due to asymmetrical information between buyer and seller (Drummond, 1992; Evans, 1995).

\section{Marketing costs}

Having a larger share of consumer demand may be the main aim of firms today, and the utilization of scientific concepts and marketing strategies is more common \& frequent than ever. Rather of a quest to find buyers for goods, modern marketing considers making appeal to the desires, expectations and preferences of consumers. On the other hand, customer loyalty and value development for the consumer to be drawn to our given created product or service are the key focus of action in modern marketing (Smith 2014).

Marketing has two main aims, retaining present consumers of its products and services; and attracting new consumers to the products and services.

Scientific and experimental marketing developments in recent years have resulted in an extension of the spectrum of practice and an improvement in this science's success rate, thereby transforming it beyond advertisement and fostering hope and expectation.' Marketing is considered in the new definition to be just equal to satisfying the needs and expectations of the consumers (Smith, 2014; Mirza et al., 2012). 
Impact of marketing costs and the research and development

Dr. Bassant Badr Eldin Abdo \& Dr. Walid Aboubakr

Today, the pharmaceutical industry is recognizing that it will exert a large amount from its investment in drug marketing to increase the level of medication prescribing, as well as to increase the level of patient satisfaction. For example, 12 leading pharmaceutical companies spend $34 \%$ of their revenues annually on physicians updating their prescription drugs and internal marketing (Lakdawalla et al., 2013). In addition, direct to consumer advertising has been increased from $\$ 1.2 \mathrm{bn}$ (1998) to 4.5bn (2009) (Ventola, 2011).

In fact, medical knowledge in the pharmaceutical industry is extremely crucial and this is something that pharmaceutical companies pay attention to. For medical knowledge using specific approaches, such as face-to-face meetings with doctors, conducting scientific seminars and conducting research experiments, papers and journals can allow physicians to rationalize and prescribe accurate and rational medicines for patients And thus boost the efficacy of medications in treating patients and raise the level of customer satisfaction (Smith, 2014; Munos, 2009).

Several studies have assessed the association between marketing costs and pharmaceutical industry benefit. For example, in US pharmaceutical companies Morton (2000) has found a substantial relationship between advertising costs and branding. In the same way, Matraves (1999), Different results were obtained in the 
Impact of marketing costs and the research and development

Dr. Bassant Badr Eldin Abdo \& Dr. Walid Aboubakr

global level study and Frank and Salkever (1991) in the USA. Unfortunately, medical knowledge and marketing expenses are not considered to cover vulnerable people inside the drug pricing system in Egypt to hold down the drug price. The position of marketing and $R \& D$ costs is so big that we decided to research the effect of these two factors on pharmaceutical companies in this report. Profit in the Egypt Stock Exchange. There are no laws granting drug patents or other inventions in Egypt. Therefore, no regulatory organisation, particularly in the private sector, regulates drug advertisings. Testing the relation between $R \& D$ costs and advertisement costs with pharmaceutical industry profitability may be significant under these conditions.

\section{Research and development}

Production and creation of a new product would allow businesses to make enormous profits. Innovative companies can provide more value than others. Many firms will seek to gain further from copying a new product on the market (Acosta et al., 2014). The quality of this work depends on non-innovative companies having copyright limitations. Despite of patents and associated features these restrictions are placed on various industries. When such restrictions are strictly implemented, otherwise new products from companies may produce more benefits as other firms may not have the ability to copy the product. Other companies may initiate copying the product after a stated period 
Impact of marketing costs and the research and development

Dr. Bassant Badr Eldin Abdo \& Dr. Walid Aboubakr

of patent expiration, and the business will need a new product design and production plan in order to gain a competitive advantage (Wu et al., 2014; Austin, 2008).

Companies need to undertake research in order to provide inventions, and the funds invested and expended on research will ensure success in the research. For example, a research project costing millions of dollars can contribute to good product results, but a company spending tens of millions of dollars on a research project would have a greater chance of developing and delivering a successful product for other companies (Daniel et al., 2015). Different studies have shown the existence of a clear positive relationship between a patent holding company and its profitability (Ohana et al., 2004). Respecting intellectual property rights would also ensure the competitiveness of new product development for businesses, which in turn would enable firms to invest more resources on innovation (Monaghan and Monaghan, 1996).

Companies must improve their design and goods on a continuous basis. Continuous technological advances, the emergence of rivals and the rising expectations of consumers make the expansion inevitable. A marketing-based mechanism that moves, the emphasis is on business necessities. Yet a program in which the R\&D-based operations are carried out focuses on requirements that have not yet been addressed (Smith, 2014). 
Impact of marketing costs and the research and development

Dr. Bassant Badr Eldin Abdo \& Dr. Walid Aboubakr

The results of DeAngelis (2016) in large pharmaceutical firms indicated that the profits of these firms are very small, often close to $40 \%$, and they invest a lot on R\&D. Dubios et al. (2015) found that there is a strong link between creativity and market size.

Fact sheets revealed that the expense of developing new drugs is $\$ 350$ million, but $95 \%$ of drugs fail because they are not being cost-effective or safe (Herper, 2013).

The pharmaceutical industry depends primarily on extensive research in the United States. According to the Congressional Budget Office, "the pharmaceutical firms spend as many as five times more in $R \& D$ than the largest manufacturing company in the United States" (Austin, 2008).

Within the US, a pharmaceutical company's typical R\&D rate is around $17 \%$ of its revenue, which is much higher than other industries. R\&D is 10 per cent in other hi-tech sectors and 9.3 per cent in the automotive industry. According to available statistics and estimates, Egypt's share of GDP's R\&D costs is less than $1 \%$, while the Pharmaceutical industry has not even exceeded half a percent (Austin, 2008; Austin, 2008; Schweitzer, 2006; Light and Lexchin, 2012). 
Impact of marketing costs and the research and development

Dr. Bassant Badr Eldin Abdo \& Dr. Walid Aboubakr

\section{Profitability}

Specialized literature provides different rentability concepts. Sedláček (2011) describes profitability as a relation between the result obtained and the resources utilized to attain it. It is a financial term that characterizes business-related sales as a relationship between income and (most often) resources for a given period of time (Zalai et al., 2016).

Typically speaking, we consider profitability as a relative relationship between profit / loss and some context. Profitability reflects the output rate of the company activity; thus, it is a function of the efforts of the firm (Lesákova et al., 2015).

Measuring profitability is most often based on building profitability indicators which take the form of ratios. One can conclude that the productivity ratios show the overall market operation to be productive (Higgins, 2003; Gibson, 2012; Cumming \& Groh, 2018). The strength of the use, replication and recovery of capital invested in the business is expressed with the aid of them (Maynard, 2017). All the productivity metrics have in common is that they usually compare the business activity's net result with the foundation represented as the amount of capital invested or the volume of business operation. As Pavelková (2010) says, the basis for calculating a profitability 
Impact of marketing costs and the research and development

Dr. Bassant Badr Eldin Abdo \& Dr. Walid Aboubakr

ratio may be different and the name of the individual variable will be extracted accordingly.

It is important to properly assess their values after measuring various profitability ratios and to show the key factors influencing them (Gibson, 2012; Higgins, 2003; Žalai et al., 2016; Maynard, 2017). The most reasonable choice for businesses will be to compare the ratios with those of previous years and the mean industry ratios values (Revsine et al., 2015; Pavelková, 2010). A great deal of useful knowledge is gained by comparing the profitability levels of the current financial year with those of previous financial years and the mean profitability rates of the industries.

Various internal (managers of firms, employees) and external (investors, consumers, vendors, banks, society) users of knowledge are involved in productivity ratios for the purpose of achieving other goals or desires. Business executives are interested in the productivity of assets primarily in order to control assets more effectively and to assess the operations of the business more objectively; Whereas investors are more interested in equity profitability, as it demonstrates their investment's profitability. Many involved in marketing activities are interested in sales profitability, as it demonstrates the selling process ' profitability (TamUlevičiene, 2016). Financial predictor values 
Impact of marketing costs and the research and development

Dr. Bassant Badr Eldin Abdo \& Dr. Walid Aboubakr

are also important in assessing the potential stability and competitiveness of the company.

Rentability growth of the company over time is a good indicator of its performance. Increasing productivity is fairly difficult but there are many approaches to do it. The firm has to recognize factors that affect it to impact its profitability (Yazdanfar, 2013).

Profit can be seen as oxygen for a company (Maynard, 2013). If a company is profitable enough, it can invest, grow its operations and thus retain a competitive market position (Stejskal et al., 2016; Kubičková \& Procházková, 2014; Lesákova, 2014). Hence, performing the profitability analysis is crucial for any business. In conjunction with controlled inputs and outputs and their reciprocal relationships, which is reflected in the efficiency of the business reproduction process, the productivity analysis allows for more detailed knowledge of qualitative outcomes that change in the business transformation process.

\section{Methods and materials}

This work is descriptive-analytical. This research was carried out using data from the Egypt Stock Exchange and econometric methods. Combined cross-sectional and time series data for pharmaceutical firms for the years 2011 to 2019. Data were not available until 2011. Sampling is not done in the study and the sample population is Egypt Stock Exchange pharmaceutical 
Impact of marketing costs and the research and development

Dr. Bassant Badr Eldin Abdo \& Dr. Walid Aboubakr

companies subset (Of the 5 companies listed on the Stock Exchange working in the pharmaceutical industry, namely EIPICO, Alexandria Pharmaceuticals, Cairo Pharmaceuticals, Arab Pharmaceuticals, and Nile Pharmaceuticals) Those are selected for the quality of the provided data. The businesses were selected according to the following criteria for inclusion and exclusion:

- Included conditions for inclusion:

- Companies have no adjustment in fiscal year during the time of study.

- The fiscal year finished on 31 December 2019.

- During the research period, the necessary information about the analysis was available.

- The company's main products were the pharmaceutical products.

- Exclusion criteria included:

- Companies, which had struggled during the time of review.

- Persistent or sporadic halt to trade for more than six months. 
Impact of marketing costs and the research and development

Dr. Bassant Badr Eldin Abdo \& Dr. Walid Aboubakr

- The book value of the equity of the companies was negative.

This work uses the econometric methods. The Panel Model is considered for this reason. In the model, Y (Grabowski and Mueller, 1978) represents in country I and at time $t$ a vector of dependent variables. $\mathrm{X}$ represents an endogenous variables vector, and $\beta$ shows a coefficient matrix. $U$ represents the aspect of error, too. Models included in the analysis are as follows:

$$
\begin{aligned}
\text { ROAit }= & \beta 0+\beta 1 \text { Age1it }+\beta 2 \text { DAit }+\beta 3 \text { CAit }+\beta 4 \text { Adit } \\
& +\beta 5 \text { Rdit }+\beta 6 \text { st } 1 \text { it }+\beta 7 \text { st } 2 \text { it }+ \text { Uit }
\end{aligned}
$$

Variables of the aforementioned models include: business life Age1it, capital-to-asset ratio DAit, debt-to-asset ratio CAit, marketing and advertisement costs Adit, R\&D costs Rdit, number of firmstlit fixed employees and number of businessvarying employeesst2it. Because of the nonlinear relationship between dependent and independent variables, all variables were transformed into logarithm form for calculating an estimate. Consequently, the model modified to the form below:

$$
\begin{aligned}
\ln R O A i t= & \beta 0+\beta 1 \ln A g e 1 \text { it }+\beta 2 \ln D A i t+\beta 3 \ln C A i t+\beta 4 \ln A d i t \\
& +\beta 5 \ln R \operatorname{dit}+\beta 6 \ln s t 1 \text { it }+\beta 7 \ln s t 2 i t+\text { Uit }
\end{aligned}
$$


Impact of marketing costs and the research and development

Dr. Bassant Badr Eldin Abdo \& Dr. Walid Aboubakr

Where, ln was the index in which variables were transformed into logarithms. Staff divided into fixed and regular staff represent the market share and revenue of the company and therefore have a longand short-term productivity index. Set employees include full-time workers who are often working for a long defined period in a company with an official employment contract. Regular staff include those who do not have long-term contracts with the company and who earn their wages every day. We also separated daily and fixed employees because studies have shown that fixed employees have more opportunities to work, and their job is more productive relative to daily employees (Shearer, 2004; Freeman and Lazear, 1994). When the company is profitable in the long term, the number of employees is increasing, and if the business is profitable in the short term, the number of regular workers will be increasing. For this analysis, also, the profitability of the businesses is the dependent variable. If all of the $\beta$ coefficients in relation to the related test are important, it is argued that the variable is correlated with profitability. Regarding the panel data, the model will be calculated using the ordinary least squares process. But first, the existence of either fixed or random effects, and pooled or panel effects were analysed to estimate the model. The model was eventually calculated with respect to the existence of all of these impacts.

\section{Results}

The study's descriptive findings are given in Table I. The 
Impact of marketing costs and the research and development

Dr. Bassant Badr Eldin Abdo \& Dr. Walid Aboubakr

estimated net income, advertisement costs, and $R \& D$ costs for Egypt Stock Exchange pharmaceutical companies are listed in this table.The results of estimating the model of panel data are shown in Table II. The model was first calculated with fixed effects, and the study results were processed. Then, it was measured and stored on random results. The Hausman test was used to analyze either fixed or random effects, and the Hausman test rejected the existence of fixed effects in the model, with a pvalue of 0.698 , and the existence of random effects was demonstrated. The results of estimating the model with random effects are shown in Table I. The fit goodness R2 statistics were 0.737 , which is appropriate for this model.

\section{Table I.}

Descriptive findings of the study

\begin{tabular}{|l|c|c|c|}
\hline \multicolumn{1}{|c|}{ Variable } & Mean & Minimum & Maximum \\
\hline Net Benefit & 1.4659 & 8.2157 & 8.6259 \\
\hline R\&D costs & 1.2357 & 3.1855 & 4.2557 \\
\hline Advertising costs & 1.2658 & 3.6956 & 2.3458 \\
\hline Fixed employees & 86.865 & 36 & 2,632 \\
\hline Varying employees & 73.693 & 0 & 863 \\
\hline
\end{tabular}


Impact of marketing costs and the research and development

Dr. Bassant Badr Eldin Abdo \& Dr. Walid Aboubakr

\section{Table II.}

The results of estimating panel data model

\begin{tabular}{|l|c|c|}
\hline \multicolumn{1}{|c|}{ Variable } & Coefficient & $p$-value \\
\hline Fixed employees & 1.5255 & 0.000 \\
\hline Varying employees & 1.0655 & 0.009 \\
\hline Capital to asset ratio & 0.185 & 0.022 \\
\hline R\&D costs & 0.335 & 0.126 \\
\hline Marketing costs & 0.067 & 0.075 \\
\hline Debt-to-asset ratio & 0.025 & 0.008 \\
\hline Companies' age & 1.857 & 0.532 \\
\hline
\end{tabular}

As shown in Table II, the relationship between and the number of workers and their productivity was significantly negative. It indicated that the advantages of pharmaceutical firms that are members of the Egypt Stock Exchange would diminish with an rise in the number of employees. The ratio of capital to assets has a positive impact on the profitability. The profitability would also increase, with an improvement in the capital-to-asset ratio. The debt-to-asset levels and profitability are negatively linked. High debt-to-asset ratios suggest the company is unable to repay its debts, and thus the income of the company would be that. No significant link between cost of R\&D and profitability has been identified. However, varying coefficients of $R \& D$ costs are negative, suggesting that $R \& D$ does not place anything on the company but expense in most pharmaceutical companies in the Egypt Stock Exchange section. 
Impact of marketing costs and the research and development

Dr. Bassant Badr Eldin Abdo \& Dr. Walid Aboubakr

The effect of marketing costs on productivity was marginal and only at a level of 10 per cent was positive and significant. The cost of marketing has two opposite implications for profitability On the one hand, they are seen as a form of expense and result in a decrease in the productivity of firms and, on the other hand, with a rise in demand, they contribute to higher profits for businesses. Unless the rise in income cannot offset the marketing expenses of the firms, the marketing and advertisement expenses would be considered inefficient. In the present analysis, the effect on benefit of the marketing costs has been negligible.

\section{Discussion and conclusion}

No important association between the $R \& D$ costs and the productivity of the company was found in the present report. As noted, factors like constant technological change, the presence of rivals and the changing tastes of consumers make $R \& D$ costs in production inevitable. In Egypt, the pharmaceutical industry (where developments in drug manufacturing technology are less rapid), the lack of competitiveness between these industries has made the effect on profitability of R\&D costs negligible (Sari et al., 2015). In Egyptian drug pricing, companies do not have enough regulations, so after calculating so deducting costs such as raw materials, packaging, etc. for each drug, they submit their proposed drug prices to the Ministry of Health ( $\operatorname{Rad}$ et al., 2015). First, the final price is decided by the health ministry and the 
Impact of marketing costs and the research and development

Dr. Bassant Badr Eldin Abdo \& Dr. Walid Aboubakr

prices in the pricing scheme may be reduced by the government; Too little attention is paid to $R \& D$ and to the quality of patents. Therefore, pharmaceutical firms with higher costs of $R \& D$ are faced with more costs of production, but these changes do not prorate drug prices. There are several issues with this pricing approach for pharmaceutical products in the country including:

- Lack of consideration in the drug pricing scheme for human principles, information and technology used to manufacture the drug.

- Same treatment for all suppliers and all pharmaceutical products (although the level of experience and technical importance of the different internal development drugs differ).

- Lack of consideration in the drug pricing scheme for human principles, information and technology used to manufacture the drug.

- Determination of drug prices for future periods on the basis of preceding period cost records, given the inflation in the country;

- Failure to quantify standard costs (GMT), R\&D costs and the cost of experimental drug pricing details.

- Failure to quantify authentication, accreditation and tracking costs of all production products used for drug pricing; 
Impact of marketing costs and the research and development

Dr. Bassant Badr Eldin Abdo \& Dr. Walid Aboubakr

- Failure to quantify costs associated with the proof of drug equivalence, in compliance with the current international drug quality requirements and guidelines.

- Unfair financial risks of the pharmaceutical industry's investments sleep on product pricing (World Health Organization, 2008a, 2008b; Cheraghali, 2013; Ewen, 2010).

Pricing positions are a high-risk approach that can have a limited effect on lowering health sector-related costs in a short period of time but carry much higher costs due to long-term reduced $R \& D$ costs of new medicines. In comparison, the existence of a university-industry partnership in the Egyptian pharmaceutical industry is very pale to have a strong $R \& D$ program. Failure to uphold values such as patent law in Egypt also affects the mitigated position of the expense of research and development (Cheraghali, 2013; World Health Organization, 2001).

There were no major relationships between cost of research and development and profitability. The explanation can be explained by the fact that $R \& D$ costs are competitive in some companies and contribute to increased productivity, while in others the costs do not result in profit and instead place additional costs on businesses and decrease their income. In view of the fact that the effects of $R \& D$ costs on productivity in various companies are inconsistent in this analysis, this effect was therefore not 
Impact of marketing costs and the research and development

Dr. Bassant Badr Eldin Abdo \& Dr. Walid Aboubakr

important because of the opposite effects mentioned above. Through a cross-sectional study Grobowskey and Muller found that spending by companies through $R \& D$ improves the productivity of companies. First, after the model has changed its profit rate, They showed that $\mathrm{R} \& \mathrm{D}$ makes businesses more effective (Grabowski and Mueller, 1978).

Perry and Grinaker looked at the competitiveness of the R\&D costs plans of 99 major American corporations in the USA. The results showed cost of $R \& D$ on profitability was successful. This effect constituted over a quarter of the overall productivity effect. $\mathrm{R} \& \mathrm{D}$ costs were also raised during economic booms but no decreases were found during economic stagnations (Perry and Grinaker, 1994).

In a same report, Verbeek and Debackere (2006) have concluded that, by analysing $\mathrm{R} \& \mathrm{D}$ prices, American businesses are increasing their potential profitability. Javaheri and Zabihidan studied the effect of $R \& D$ costs on the output of companies in the Egyptian market. The study results showed that higher amounts spent on R\&D in an industry lead to a decline in income in that industry because the $R \& D$ operation raises firm costs and results in decrease in profitability. Consequently, the results suggested that on average there is less incentive to invest money on R\&D in firms in industries where there is higher productivity (Sadraei Javaheri et al., 2011). In their study Shah et al. (2008) analyzed 
Impact of marketing costs and the research and development

Dr. Bassant Badr Eldin Abdo \& Dr. Walid Aboubakr

the relationship between profitability and $R \& D$ costs in the pharmaceutical and electronics industries, based on the research results, there is a positive and important relationship between $R \& D$ costs in the pharmaceutical and electronics industries and profitability ratios.

In addition, no significant link between advertising costs and productivity has been observed in the current study. It is also possible to relate negligible advertisement and advertising costs to factors such as the lack of competition in Egypt's pharmaceutical sectors, the pricing structure of drugs using conventional marketing strategies and the lack of updating technologies.

Unfortunately, Egypt's drug pricing scheme does not accept scientific knowledge and marketing expenses to hold down medication prices to protect the vulnerable. During the years 1985 to 1994 Graham and Frankenberger investigated the relationship between advertisement and competitiveness of American companies. Their results found that, for three years, ads had a beneficial impact on productivity, and the most impact was during the years when the commercials were performed and their effect would be reduced over time.

They also concluded that the impact of ads in service-based businesses was seen for two years, and that the size of the 
Impact of marketing costs and the research and development

Dr. Bassant Badr Eldin Abdo \& Dr. Walid Aboubakr

industry was seen in manufacturing firms for four years (Graham and Frankenberger, 2000). In their research, Chauvin and Hirschey (1993) analyzed the relationship between advertising costs and profitability, and based on the research results a positive and important relationship existed between advertising costs and profitability.

A negative association between the debt and profitability of companies and a positive relation between capital and profitability has been identified in this analysis. Komonen (2002) analyzed the impact of factors such as selling rate (size), number of manpower, raw materials, the amount of capital and maintenance cost of other factors on the income of manufacturing firms. His research found that the rate of revenue and the cost of labor has a greater effect on the income of manufacturing firms than other variables. Cinca et al. (2005) demonstrated a favorable relationship between the size and profitability ratios of European firms. Artikis et al. (2007) also concluded that the increased debt rate to the assets of Greek firms would contribute to a reduction in profitability.

This study had its limitations. Second, data were not available from pharmaceutical firms which were not members of the Egypt Stock Exchange Organization. Every business submitted the available data to the Stock Exchange Organisation, and it could be adjusted by the company's accountants and financial managers 
Impact of marketing costs and the research and development

Dr. Bassant Badr Eldin Abdo \& Dr. Walid Aboubakr

to demonstrate that the company's financial situation is spuriously fine.

\section{Conclusion}

The law of R\&D and marketing is not very relevant in the Egyptian Pharmaceutical industry. The corporations are not inspired enough to invest on ads. This is because the prices are set by the Ministry of Health and the firms have no influence in the pricing of drugs. Furthermore, the government has not yet developed any patent law and investing in R\&D is not costeffective because other companies may copy the new drugs without concern. The effect of R\&D and marketing costs on private pharmaceutical industry in Egypt is suggested to be evaluated for further studies. 
Impact of marketing costs and the research and development

Dr. Bassant Badr Eldin Abdo \& Dr. Walid Aboubakr

\section{References:}

Acosta, A., Ciapponi, A., Aaserud, M., Vietto, V., Austvoll-Dahlgren, A., Kosters, J.P., Oxman, A.D., Ramsay, C. and Sturm, H. (2014), "Pharmaceutical policies: effects of reference pricing, other pricing, and purchasing policies", The Cochrane Database of Systematic Reviews, No. 2, p. CD005979.

Artikis, G.P., Eriotis, N., Vasiliou, D. and Ventoura-Neokosmidi, Z. (2007), "How firm characteristics affect capital structure: an empirical study", Managerial Finance, Vol. 33 No. 5, pp. 321-331.

Austin, D.H. (Ed.) (2006), Research and Development in the Pharmaceutical Industry, Congress of the United States, Congressional Budget Office.

Chauvin, K.W. and Hirschey, M. (1993). "Advertising R\&D expenditures and the market value of the firm”, Financial Management, Vol. 22 No. 4, pp. $128-140$.

Cheraghali, A.M. (2013), "Impacts of international sanctions on Iranian pharmaceutical market”, DARU: Journal of Pharmaceutical Sciences, Vol. 21 No. 1, p. 64.

Cinca, C.S., Molinero, C.M. and Larraz, J.G. (2005), "Country and size effects in financial ratios: a European perspective", Global Finance Journal, Vol. 16 No. 1, pp. 26-47.

Cumming, D., \& Groh, A. R (2018). Entrepreneurial finance: Unifying themes and future directions. Journal of Corporate Finance, 50(2018), 538-555. https://doi.org/10.2139/ssrn.3102588.

Evans, R.G. (1995), "Manufacturing consensus, marketing truth: guidelines for economic evaluation", Annals of Internal Medicine, Vol. 123 No. 1, pp. 59-60. 
Impact of marketing costs and the research and development

Dr. Bassant Badr Eldin Abdo \& Dr. Walid Aboubakr

Ewen, M. (2010), "Medicine prices, availability, affordability and price components", WHO, WIPO, and WTO Joint, Technical Symposium, Cairo.

Daniel, G.W., Caze, A., Romine, M.H., Audibert, C., Leff, J.S. and McClellan, M.B. (2015), "Improving pharmaceutical innovation by building a more comprehensive database on drug development and use", Health Affairs, Vol. 34 No. 2, pp. 319-327.

DeAngelis, C.D. (2016), "Big pharma profits and the public loses", The Milbank Quarterly, Vol. 94 No. 1, pp. 30-33. Drummond, M. (1992), “Science or marketing?", Pharmacoeconomics, Vol. 1 No. 1, pp. 8-13.

Dubois, P., de Mouzon, O., Scott-Morton, F. and Seabright, P. (2015), "Market size and pharmaceutical innovation", The RAND Journal of Economics, Vol. 46 No. 4, pp. 844-871.

Frank, R.G. and Salkever, D.S. (1991), Pricing, Patent Loss and the Market for Pharmaceuticals, National Bureau of Economic Research.

Freeman, R.B. and Lazear, E.P. (1994), An Economic Analysis of Works Councils, National Bureau of Economic Research.

Gibson, C. (2012). Financial Reporting and Analysis. Using Financial Accounting Information. Mason: South-Western Ceng age Learning.

Grabowski, H.G. and Mueller, D.C. (1978), "Industrial research and development, intangible capital stocks, and firm profit rates", The Bell Journal of Economics, Vol. 9 No. 2, pp. 328-343.

Graham, R.C. and Frankenberger, K.D. (2000), "The contribution of changes in advertising expenditures to earnings and market values", Journal of Business Research, Vol. 50 No. 2, pp. 149-155. 
Impact of marketing costs and the research and development

Dr. Bassant Badr Eldin Abdo \& Dr. Walid Aboubakr

Griliches, Z. (1979), "Issues in assessing the contribution of research and development to productivity growth", The Bell Journal of Economics, Vol. 1 No. 1, pp. 92-116.

Herper, M. (2013), “The cost of creating a new drug now $\$ 5$ billion, pushing big pharma to change", Forbes, August, p. 22.

Higgins, R. C. (2003). Analysis for Financial Management. New York: McGraw-Hill/Irwin.

Komonen, K. (2002), “A cost model of industrial maintenance for profitability analysis and benchmarking", International Journal of Production Economics, Vol. 79 No. 1, pp. 15-31.

Kubíčková, L., \& Procházková, L. (2014). Success evaluation of small and medium-sized enterprises in terms of their participation in the internationalization process. E\&M Ekonomie a Management, 17(2), 131-145. https://doi. o rg/10.15240/tul/001 /2014-2-010.

Lakdawalla, D., Sood, N. and Gu, Q. (2013), "Pharmaceutical advertising and Medicare Part D”, Journal of Health Economics, Vol. 32 No. 6, pp. 1356-1367.

Lesákova, L., Gundová, P, \& Elexa, L. (2015). Finančno-ekonomická analýza podniku. Banská Bystrica: Ekonomická fakulta Univerzity Mateja Bela.

Light, D.W. and Lexchin, J.R. (2012), "Pharmaceutical research and development: what do we get for all that money?", BMJ, Vol. 345, p. e4348.

Matraves, C. (1999), "Market structure, R\&D and advertising in the pharmaceutical industry", Journal of Industrial Economics, Vol. 47 No. 2, pp. 169-194. 
Impact of marketing costs and the research and development

Dr. Bassant Badr Eldin Abdo \& Dr. Walid Aboubakr

Maynard, J. (2017). Financial accounting, reporting, and analysis. Oxford University Press.

Mirza, K., Rashid, M. and Hunjra, A.I. (2012), Marketing Ethics and Pharmaceutical Industry, LAP LAMBERT Academic Publishing, Germany.

Monaghan, M.J. and Monaghan, M.S. (1996), "Do market components account for higher US prescription prices?”, The Annals of Pharmacotherapy, Vol. 30 No. 12, pp. 1489-1494.

Morton, F.M.S. (2000), "Barriers to entry, brand advertising, and generic entry in the US pharmaceutical industry", International Journal of Industrial Organization, Vol. 18 No. 7, pp. 1085-1104.

Munos, B. (2009), "Lessons from 60 years of pharmaceutical innovation", Nature Reviews Drug Discovery, Vol. 8 No. 12, pp. 959-968.

Ohana, P., Tardieu, S., Blin, O., Tassy, S. and Sambuc, R. (2004), "Drug patents and other ways to protect pharmaceutical research", Therapie, Vol. 59 No. 2, pp. 253-257.

Pavelková, D. (2010). Finanční analýza - komplexní průvodce s př́klady. Praha: Grada Publishing.

Revsine, L, Collins, D., \& Johnson, B. (2015). Financial Reporting and Analysis. New York: McGraw-Hill Education.

Perry, S. and Grinaker, R. (1994), "Earnings expectations and discretionary research and develop", Accounting Horizons, Vol. 8 No. 4, p. 43.

Rad, E.H., Rezaei, S. and Fallah, R. (2015), "Physician labor participation and unemployment rate in Iran", Shiraz E-Medical Journal, Vol. 16 No. 4, p. e23620. 
Impact of marketing costs and the research and development

Dr. Bassant Badr Eldin Abdo \& Dr. Walid Aboubakr

Sadraei Javaheri, A., Zabihidan, M. and Balaghi, A. (2011), “An investigation on the effects of advertising and industrial concentration on profitability of Iranian food products and beverages", Economics and Agriculture Journal, Vol. 5 No. 3, p. 15.

Sari, A.A., Rezaei, S., Rad, E.H., Dehghanian, N. and Chavehpour, Y. (2015), "Regional disparity in physical resources in the health sector in Iran: a comparison of two time periods", Iranian Journal of Public Health, Vol. 44 No. 6, p. 848.

Schall, L.D. and Haley, C.W. (1980), Introduction to Financial Management, McGraw-Hill Companies.

Schweitzer, S.O. (2006), Pharmaceutical Economics and Policy, Oxford University Press.

Sedláček, J. (2011). Finanční analýza podniku. Brno: Computer Press.

Shah, S.Z.A., Stark, A.W. and Akbar, S. (2008), "Firm size, sector and market valuation of R\&D expenditures", Applied Financial Economics Letters, Vol. 4 No. 2, pp. 87-91.

Shearer, B. (2004), "Piece rates, fixed wages and incentives: evidence from a field experiment”, The Review of Economic Studies, Vol. 71 No. 2, pp. 513-534.

Smith, M.C. (2014), Principles of Pharmaceutical Marketing, Routledge.

Stejskal, J., Mikušová-Meričková, B., \& Prokop, V. (2016). The cooperation between enterprises: significant part of the innovation process - a case study of the Czech machinery industry. E\&M Ekonomie a Management, 19(Z), 110-121. https://doi.org/10.15240/tuI/001 /20163008 . 
Impact of marketing costs and the research and development

Dr. Bassant Badr Eldin Abdo \& Dr. Walid Aboubakr

Tamulevičiene, D. (2016). Methodology of Complex Analysis of

Companies' Profitability. Entrepreneurship and Sustainability Issues, 4(1), 53-63. https://doi.Org/10.9770/jesi.2016.4.1 (5).

Yazdanfar, D. (2013). Profitability determinants among micro firms: evidence from Swedish data. International Journal of Managerial Finance, 9(2), 151-160. https://doi. org/10.1108/17439131311307565.

Ventola, C.L. (2011), "Direct-to-consumer pharmaceutical advertising: therapeutic or toxic?", P\&T: A Peer-Reviewed Journal for Formulary Management, Vol. 36 No. 10, pp. 669-684.

Verbeek, A. and Debackere, K. (2006), "Patent evolution in relation to public/private R\&D investment and corporate profitability: evidence from the United States: a compilation of relationships based on long run time series techniques", Scientometrics, Vol. 66 No. 2, pp. 279-294.

World Health Organization (2001), How to Develop and Implement a National Drug Policy, World Health Organization.

World Health Organization (2008a), Measuring Medicine Prices, Availability, Affordability and Price Components, World Health Organization.

World Health Organization (2008b), Medicine Prices, Availability, Affordability and Price Components: A Synthesis Report of Medicine Price Surveys Undertaken in Selected Countries of the WHO Eastern Mediterranean Region, World Health Organization.

Wu, J., Xu, J., Liu, G. and Wu, J. (2014), "Pharmaceutical pricing: an empirical study of market competition in Chinese hospitals", Pharmacoeconomics, Vol. 32 No. 3, pp. 293-303.

Zalai, K. etai. (2016). Finančno-ekonomická analýza podniku. Bratislava: Sprint 2. 